How to Cite: Sinitsyna, A.A., \& Il'yasov, S.G. Synthesis of alkyl derivatives of 3,7,10-trioxo-2,4,6,8,9,11-hexaaza[3.3.3]propellane and evaluation of their biological activity. (2021) Phosphorylation of glycoluryl derivatives with phosphorus pentachloride. Bulletin of the University of Karaganda - Chemistry, 101(1), 19-26. https://doi.org/10.31489/2021Ch1/19-26

\author{
A.A. Sinitsyna*, S.G. Il'yasov \\ Institute for Problems of Chemical and Energetic Technologies, \\ Siberian Branch of the Russian Academy of Sciences (IPCET SB RAS), Biysk, Russia \\ (*Corresponding author's e-mail: nastya.sinitsyna.1994@mail.ru)
}

\title{
Synthesis of alkyl derivatives of 3,7,10-trioxo-2,4,6,8,9,11-hexaaza[3.3.3]propellane and evaluation of their biological activity
}

\begin{abstract}
Today 3,7,10-trioxo-2,4,6,8,9,11-hexaaaza[3.3.3]propellane (THAP) has not yet received widespread research attention due to the complexity of the synthesis. This work is devoted to the development of a method for the THAP derivatives synthesis, as well as to the study of their biological activity in comparison with alkyl-substituted glycolurils (subject of comparison). THAP was $\mathrm{N}$-alkylated to furnish novel hexaalkyl derivatives of THAP with methyl, ethyl and propyl substituents. The conditions for obtaining the maximum yield of the target product were optimized on the base of methyl derivative. The reaction proceeded in DMSO/KOH at $75-80{ }^{\circ} \mathrm{C}$ for 13 hours in a moderate yield of $56 \%$. The ethyl and propyl derivatives of THAP were synthesized under the same conditions. The biological activity of the obtained THAP alkyl derivatives and glycoluril alkyl derivatives was evaluated against Sporosarcina ureae, Bacillus pumilus, Salmonella typhimurium and Staphylococcus aureus bacteria and influenza A virus. All the samples were found to exhibit antibacterial activity against Staphylococcus aureus. It was shown that 2,4,6,8,9,11-hexapropyl-THAP, ditert-butyl-diphenyl-, di-tert-butyl-dibenzyl-, di-tert-butyl-dimethyl- and di-isopropyl-dibenzylglycoluril, have exhibited also toxicity to living cells besides antiviral activity.
\end{abstract}

Keywords: propellane, azapropellane, THAP, glycoluril, N-alkylation, biological activity, influenza virus, Sporosarcina ureae, Bacillus pumilus, Salmonella typhimurium, Staphylococcus aureus

\section{Introduction}

Propellanes are molecules with a central single (ethane) bond and three bridged rings (carbon or heteroatomic) [1]. They are found in natural resources [2-3] and are widely applied in polymeric materials, medicines, pesticides and so on [4-6]. Zalkow et al. [7] were the first to isolate sesquiterpene modephene from the poisonous plant Isocoma Wrightii in 1978. It was the first compound with a [3.3.3]propellane skeleton discovered in natural products [3.3.3]. Due to their structure, modephene and its derivatives exhibit a variety of biological activity $[8,9]$ and its toxicity can passivate certain biological enzymes and selectively inhibit anti-proliferation of some cancer cells. Thus, propellanes have been in focus of many chemists and biologists over a few last decades.

Among propellanes, heterocyclic compounds, especially those with nitrogen atoms (azapropellanes), are of considerable interest, since they can be easily be functionalized.

Research on the synthesis of azapropellanes was carried out by Ashkenazi et al. [10]. Shin and coworkers managed to have synthesized propellane bearing five nitrogen atoms through the glycoluril derivative in three stages in 2014 [11].

Lee, Zhang and co-workers developed a synthetic method for 3,7,10-trioxo-2,4,6,8,9,11hexaaza[3.3.3]propellane (Fig. 1) [12-13].
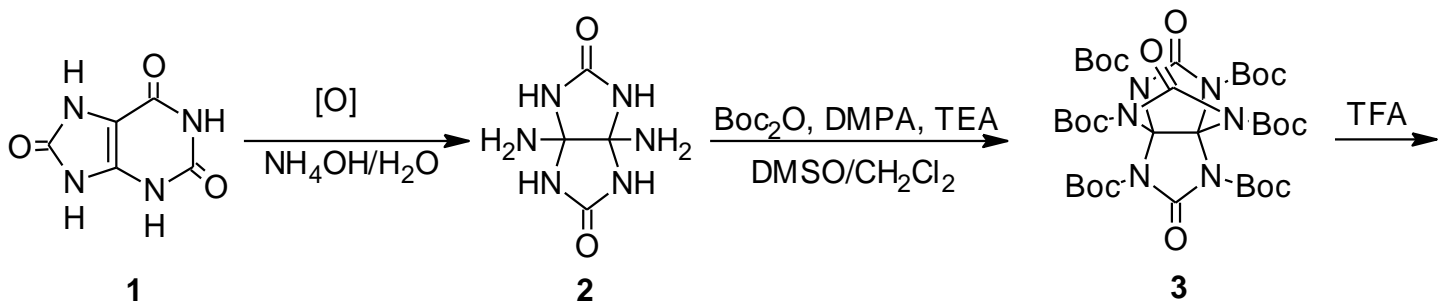<smiles>O=C1NCC2(N1)NC(=O)NC(=O)N2</smiles>

Figure 1. A synthetic protocol for 3,7,10-trioxo-2,4,6,8,9,11-hexaaza[3.3.3]propellane 
This method consists of three stages. At the first stage the uric acid (1) is oxidized by potassium hexacyanoferrate to form 1,5-diaminoglycoluril (2). At the second stage 3,7,10-trioxo-2,4,6,8,9,11-hexaBoc-2,4,6,8,9,11-hexaaza[3.3.3]propellane (3) is obtained from 1,5-diaminoglycoluril (2) by a tricyclization reaction. Afterwards, Boc-deprotection is performed (third stage) with trifluoroacetic acid to form propellane (4) with six nitrogen atoms.

Lee et al. [12] obtained 3,7,10-trioxo-2,4,6,8,9,11-hexa-benzyl-THAP (5a) and 3,7,10-trioxo2,4,6,8,9,11-hexa-allyl-THAP (5b) (Fig. 2) in DMSO-DMF-NaH under inert nitrogen. The resultant products were extracted with ethyl acetate and then purified by column chromatography.<smiles>NC(=O)C12NC(=O)NC1(CC(Br)Br)NC(=O)N2</smiles>

4<smiles>[R]N1C(=O)N([R])C2(C(=O)N1[R])N([R])C(=O)N2[R]</smiles>

$5 \mathrm{a}, \mathrm{b}$

Figure 2. A synthetic protocol for alkyl derivatives of 3,7,10-trioxo-2,4,6,8,9,11-hexaaza[3.3.3]propellane

However, there is no information in the literature on the synthesis of alkyl derivatives of THAP. Therefore, the present study was aimed at developing a synthetic method for alkyl derivatives of 3,7,10-trioxo2,4,6,8,9,11-hexaaza[3.3.3]propellane and evaluating their biological activity in comparison with alkylsubstituted glycolurils previously obtained.

\section{Experimental}

\section{General procedure}

3,7,10-trioxo-2,4,6,8,9,11-hexaaza[3.3.3]propellane $(0.4 \mathrm{~g}, 0.002 \mathrm{~mol})$ and $\mathrm{KOH}(1.12 \mathrm{~g}, 0.02 \mathrm{~mol})$ were added to DMSO $(15 \mathrm{~mL})$, stirred for $30 \mathrm{~min}$ at $40^{\circ} \mathrm{C}$, and then the corresponding alkyl halide $(0.02 \mathrm{~mol})$ was added. The reaction mixture was heated to $75-80^{\circ} \mathrm{C}$ and kept for $5-13 \mathrm{~h}$. After completion of the reaction, the resulting salt was collected by filtration, and the initial solution was extracted $(15 \mathrm{~mL} \times 3)$ with a mixture of water/methylene chloride in a ratio of 1:1. The organic layer was evaporated to give a white powder.

The analysis of the obtained compound was determined by HPLC on an Agilent 1200 chromatograph. Separation was carried out on a chromatographic column Zorbax SB C-18 $(150 * 2,1 \mathrm{~mm}$, particle size $5 \mu \mathrm{m})$ from Agilent Technologies (USA), with the precolumn (Zorbax SB C-18 12,5*2,1 mm, particle size $5 \mu \mathrm{m}$ ). $0.1 \%$ trifluoroacetic acid (solvent A) and acetonitrile (solvent B) were used as the mobile phase. The column temperature was $25^{\circ} \mathrm{C}$. The composition of the mobile phase was measured in a gradient mode: the concentration of solvent B was measured from $2 \%$ to $40 \%$ within $10 \mathrm{~min}$. The flow rate of the mobile phase was $0.25 \mathrm{ml} / \mathrm{min}$. The duration of the session was 20 minutes. Column conditioning between consecutive injection was $15 \mathrm{~min}$. Detection was carried out at $225 \mathrm{~nm}$ wave-length. The sample volume was $5 \mu 1$.

3,7,10-Trioxo-2,4,6,8,9,11-hexamethyl-2,4,6,8,9,11-hexaaza[3.3.3]propellane (5c): Yield: $0.32 \mathrm{~g}$ (56\% of the theor.). $\mathrm{Mp}=256-258^{\circ} \mathrm{C}$. IR, $\mathrm{cm}^{-1}: 2944,2602,1690,1629,1503,1401,1371,1273,1207$, $1156,1008,832,702 .{ }^{1} \mathrm{H}$ NMR $(500 \mathrm{MHz}, \mathrm{DMSO}-d 6) \delta 3.00\left(\mathrm{~s}, 18 \mathrm{H}, \mathrm{CH}_{3}\right) ;{ }^{13} \mathrm{C}$ NMR $(126 \mathrm{MHz}$, DMSOd6) $157.43(\mathrm{C}=\mathrm{O}), 90.64$ (Ctert.), $26.72\left(\mathrm{CH}_{3}\right)$.

3,7,10-Trioxo-2,4,6,8,9,11-hexaethyl-2,4,6,8,9,11-hexaaza[3.3.3]propellane $\quad(5 d): \quad$ Yield: $\quad 0.33 \mathrm{~g}$ (45\% of the theor.). $\mathrm{Mp}=220-222^{\circ} \mathrm{C}$. IR, $\mathrm{cm}^{-1}: 2976,2935,2872,1696,1622,1496,1437,1369,1354$, $1279,1218,1060,966,862,756,702 .{ }^{1} \mathrm{H}$ NMR (500 MHz, DMSO- $\left.d 6\right) \delta 3.50-3.45\left(\mathrm{q}, J=7 \times 3 \mathrm{~Hz}, 2 \mathrm{H}, \mathrm{CH}_{2}\right)$, $1.01-0.98\left(\mathrm{t}, J=7 \times 2 \mathrm{~Hz}, 3 \mathrm{H}, \mathrm{CH}_{3}\right) ;{ }^{13} \mathrm{C}$ NMR (126 MHz, DMSO-d6) $156.49(\mathrm{C}=\mathrm{O}), 96.24$ (Ctert.), 36.21 $\left(\mathrm{CH}_{2}\right), 14.31\left(\mathrm{CH}_{3}\right)$.

3,7,10-Trioxo-2,4,6,8,9,11-hexapropyl-2,4,6,8,9,11-hexaaza[3.3.3]propellane (5e): Yield: $0.46 \mathrm{~g}$ (51\% of the theor.). $\mathrm{Mp}=180-182^{\circ} \mathrm{C} . \mathrm{IR}, \mathrm{cm}^{-1}: 2967,2936,2876,1704,1484,1426,1344,1291,1200$, $1078,910,884,847,809.749 .{ }^{1} \mathrm{H}$ NMR $\left(500 \mathrm{MHz}\right.$, DMSO-d6) $\delta 3,36-3,39\left(\mathrm{~m}, 12 \mathrm{H}, \mathrm{CH}_{2}\right), 1.36-1.41(\mathrm{~m}$, $\left.12 \mathrm{H}, \mathrm{CH}_{2}\right), 0.77-0.81\left(\mathrm{t}, J=7.4 \times 2 \mathrm{~Hz}, 18 \mathrm{H}, \mathrm{CH}_{3}\right) ;{ }^{13} \mathrm{C}$ NMR $(100 \mathrm{MHz}$, DMSO-d6) $156.53(\mathrm{C}=\mathrm{O}), 87.01$

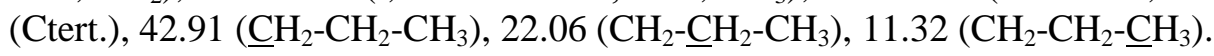


Evaluation of biological activity

To determine the antibacterial activity, two-fold dilution of experimental preparations (volume $100 \mu \mathrm{l}$ ) was made in the cells of a 96-well culture plate with a U-shaped bottom on MPB medium (mesopatamia broth). $100 \mu \mathrm{l}$ of an overnight culture diluted to a concentration of $106 \mathrm{cells} / \mathrm{ml}$ was added to each well. Incubation took place at $37^{\circ} \mathrm{C}$ for 40 hours. Determination of optical density in relation to control (growth of bacterial culture without preparation) was performed.

To examine the antiviral activity in vitro, two methods were used:

1) the inhibition of the virus-induced cytopathic effect was determined visually under a microscope [17];

2 ) by changing the absorption of the vital dye by cells - neutral red $[17,18]$.

For this purpose, a 96-well plate was seeded with a MDCK (dog, kidney, cell monolayer) cell line, with a seed dose of $2 \times 10^{4}$ cell per well. After $90 \%$ of the monolayer was formed (20-h incubation at $37^{\circ} \mathrm{C}$ under $\left.5 \% \mathrm{CO}_{2}\right)$, the influenza A/California/ 07/09 $(\mathrm{H} 1 \mathrm{~N} 1 \mathrm{pdm} 09)$ virus strain was inserted at a dose of $100 \mathrm{TCID}_{50}$ per well. This dose is equivalent to the multiplicity of infection at 0.001 of infection particles per cell. 30 minutes after infection, the test sample contained in the culture medium was placed in the wells and incubated at $37{ }^{\circ} \mathrm{C}$ under $5 \% \mathrm{CO}_{2}$ for $72 \mathrm{~h}$. After that, neutral red $(0.34 \%$ final concentration) was added into each well, the cells were washed in $1.5 \mathrm{~h}$, and a solution $\left(0.1 \mathrm{M} \mathrm{NH}_{4} \mathrm{H}_{2} \mathrm{PO}_{4}\right.$ and $96 \%$ ethanol in equal volumes) was added for the stain extraction, and the optical density of the liberated stain was measured at a wavelength of $490 \mathrm{~nm}$. The antiviral activity of the compound was estimated as a dose (concentration) of the test drug, which $50 \%$ inhibits the viral reproduction or $\mathrm{IC}_{50}$. Although $\mathrm{IC}_{50}$ was estimated by the two methods (determination of virus-induced cytopathic effect and incubation with neutral red), here we presented data obtained only with neutral red as more objective.

To assess the toxicity of the compounds, the 96-well plate was seeded with a MDCK cell culture with a seed dose of $2 \times 10^{4}$ cells per well. After a 20 -hour incubation at $37^{\circ} \mathrm{C}$ in an atmosphere of $5 \% \mathrm{CO}_{2}$, the compounds dissolved in a MEM medium (Gibco) containing $5 \%$ fetal bovine serum were introduced. Three days after incubation, the inhibition percentage of cell proliferation was evaluated using neutral red, as described above. The toxicity of the compounds was estimated as a dose (concentration) of the test drug at which $50 \%$ cells are died $\left(\mathrm{CD}_{50}\right)$.

The therapeutic index or index of selectivity (IS) was determined as the ratio of $\mathrm{CD}_{50}$ to $\mathrm{IC}_{50}$

\section{Results and Discussion}

Synthesis of alkyl derivatives of 3,7,10-trioxo-2,4,6,8,9,11-hexaaza[3.3.3]propellane

It would be logical to apply the glycoluril alkylation methods to THAP since it molecule is characterized by the presence of three imidazolidinone rings and has a structure similar to glycoluril. We have earlier developed a synthetic method for tetrasubstituted glycolurils with mono- and heterofunctional substituents in an acetonitrile/KOH medium $[14,15]$. The method incorporates the alkyl groups into the partially substituted glycoluril and uses a low-boiling solvent to simplify the isolation of reaction products.

The alkylation reaction of 3,7,10-trioxo-2,4,6,8,9,11-hexaaza[3.3.3]propellane was carried out under conditions similar to the alkylation of glycoluril. In this case, the yield of hexaaryl derivatives of THAP was found low and reached only $6-8 \%$ in acetonitrile medium.

That is why we investigated the effects of different solvents (DMSO, DMF, ethanol, 1,4-dioxane and methylene chloride), reaction temperature and bases on the target product yield by an example of the $\mathbf{5 c}$ synthesis (Table 1).

$\mathrm{Tab} l \mathrm{e} 1$

Selection of synthesis conditions for $2,4,6,8,9,11$-hexamethyl-2,4,6,8,9,11-hexaaza[3.3.3]propellane 5c

\begin{tabular}{|c|l|c|c|c|c|l|c|c|c|}
\hline Exp. & \multicolumn{1}{|c|}{ Solvent } & Base & $\begin{array}{c}\text { Reaction tem- } \\
\text { perature, }{ }^{\circ} \mathrm{C}\end{array}$ & $\begin{array}{c}\text { Yield, } \\
\%\end{array}$ & Exp. & Solvent & Base & $\begin{array}{c}\text { Reaction tem- } \\
\text { perature, }{ }^{\circ} \mathrm{C}\end{array}$ & $\begin{array}{c}\text { Yield, } \\
\%\end{array}$ \\
\hline 1 & DMSO & $\mathrm{KOH}$ & 80 & 24 & 6 & DMSO & $\mathrm{K}_{2} \mathrm{CO}_{3}$ & 80 & - \\
\hline 2 & DMF & $\mathrm{KOH}$ & 80 & 11 & 7 & DMF & $\mathrm{K}_{2} \mathrm{CO}_{3}$ & 80 & - \\
\hline 3 & Ethanol & $\mathrm{KOH}$ & 70 & - & 8 & Ethanol & $\mathrm{K}_{2} \mathrm{CO}_{3}$ & 70 & - \\
\hline 4 & 1,4-Dioxane & $\mathrm{KOH}$ & 80 & - & 9 & $1,4-$ Dioxane & $\mathrm{K}_{2} \mathrm{CO}_{3}$ & 80 & - \\
\hline 5 & Methylene chloride & $\mathrm{KOH}$ & 40 & - & 10 & Methylene chloride & $\mathrm{K}_{2} \mathrm{CO}_{3}$ & 40 & - \\
\hline
\end{tabular}

Note. «-» THAP was quantitatively isolated back; no reaction has occurred. 
As can be seen from Table 1, the N-alkylation reaction took place only at $80{ }^{\circ} \mathrm{C}$ and only in the two solvents such as DMSO and DMF. It is also evident that the yield of the target product $\mathbf{5 c}$ in DMSO is almost 2 times more than that in DMF. The superbasic medium DMSO / KOH was selected for further research based on these preliminary results (Table 1). The results of the THAP alkylation with methyl iodide in the superbasic medium as a function of the reaction temperature and time are given in Figure 3.

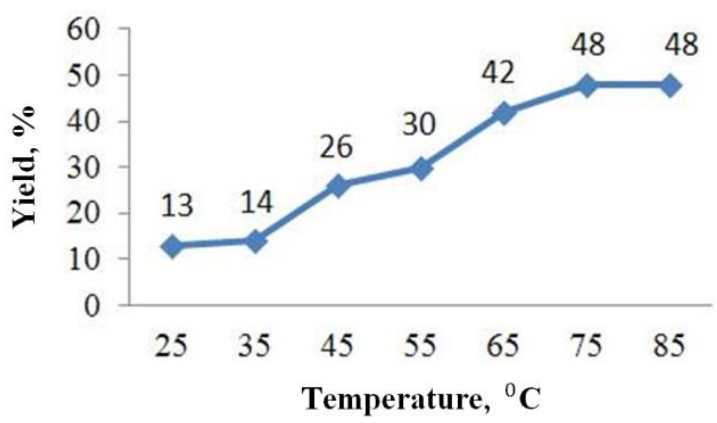

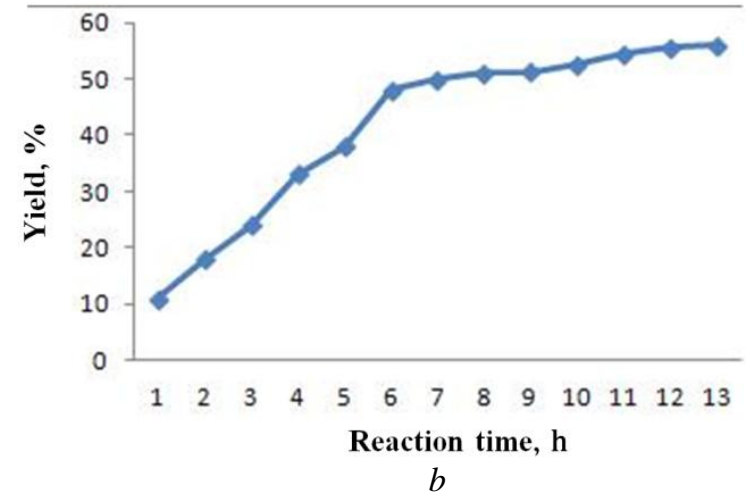

$b$

Figure 3. Dependence of the 5c yield: $(a)$ on the reaction temperature (reaction time 6 hours) and $(b)$ on the reaction time (temperature $75^{\circ} \mathrm{C}$ )

Figure $3 a$ shows that an increase in the reaction temperature from $25^{\circ} \mathrm{C}$ to $85^{\circ} \mathrm{C}$ led to a smooth raising in the content of product $5 \mathbf{c}$ from $12 \%$ to $48 \%$. An increase of the alkylation time from 6 to 8 hours ( $3 b$ ) showed a slight growing in the yield of product $\mathbf{5 c}$ to $51 \%$. When the reaction time was extended to $13 \mathrm{~h}$, the yield of product $\mathbf{5 c}$ got higher insignificantly and was $56 \%$. The slowdown in the formation of reaction product $\mathbf{5 c}$ in 13 hours can be explained by the emerging of competing reactions due to the prolonged residence of the reagents in the superbasic medium at high temperature.

We sequentially have obtained THAP hexa-derivatives with methyl (5c), ethyl (5d) and propyl (5e) substituents (Fig. 4).<smiles>O=C(O)NC12NC(=O)NC1NC(=O)N2</smiles>

4

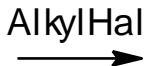<smiles></smiles>

5

R: c. $\mathrm{CH}_{3}-(56 \%)$

d. $\mathrm{C}_{2} \mathrm{H}_{5}-(45 \%)$

e. $\mathrm{C}_{3} \mathrm{H}_{7^{-}}(51 \%)$

Figure 4. Synthesis of alkyl derivatives of 3,7,10-trioxo-2,4,6,8,9,11-hexaaza[3.3.3]propellane

An attempted of isopropyl and tert-butyl groups incorporation into THAP did not lead to the expected result. This is probably due to the steric factor of the radicals.

Biological activity

The tetrasubstituted glycolurils synthesized previously $[14,15]$ and the new THAP derivatives were evaluated in vitro against some bacteria (Sporosarcina ureae, Bacillus pumilus, Salmonella typhimurium and Staphylococcus aureus) and influenza A virus. Tables 2 and 3 summarize the biological activity evaluation results. 
Table 2

Evaluation of antibacterial activity of the THAP hexaaza- derivatives and tetrasubstituted glycolurils

\begin{tabular}{|c|c|c|c|c|c|}
\hline \multicolumn{2}{|r|}{ Compound } & Sporosarcina ureae & Bacillus pumilus & $\begin{array}{l}\text { Salmonella } \\
\text { typhimurium }\end{array}$ & Staphylococcus aureus \\
\hline & $5 c$ & $1,3 \cdot 10^{-2}$ & $2,6 \cdot 10^{-2}$ & $1,3 \cdot 10^{-2}$ & $1,3 \cdot 10^{-2}$ \\
\hline & $5 d$ & $4,2 \cdot 10^{-3}$ & $8,4 \cdot 10^{-3}$ & $4,2 \cdot 10^{-3}$ & $4,2 \cdot 10^{-3}$ \\
\hline & $5 e$ & $5,9 \cdot 10^{-3}$ & no & no & $2,9 \cdot 10^{-3}$ \\
\hline $\mathbf{6 a}$ & & $4,6 \cdot 10^{-2}$ & $9,2 \cdot 10^{-2}$ & $9,2 \cdot 10^{-2}$ & $4,6 \cdot 10^{-2}$ \\
\hline $\mathbf{6 b}$ & & $2,0 \cdot 10^{-3}$ & no & no & $8,0 \cdot 10^{-3}$ \\
\hline $\mathbf{6 c}$ & & $1,2 \cdot 10^{-3}$ & no & $9,8 \cdot 10^{-3}$ & $4,6 \cdot 10^{-3}$ \\
\hline 6d & & $1,8 \cdot 10^{-2}$ & $1,8 \cdot 10^{-2}$ & $1,8 \cdot 10^{-2}$ & $8,8 \cdot 10^{-3}$ \\
\hline $6 e$ & & $4,2 \cdot 10^{-3}$ & no & no & $4,2 \cdot 10^{-3}$ \\
\hline 6f & & no & no & no & $7,0 \cdot 10^{-3}$ \\
\hline
\end{tabular}

Sporosarcina ureae are spore-forming bacteria and ammonifying microorganisms that decompose urea. They are used in agriculture for nitrogen enrichment of the soil. Bacillus pumilus are phytopathogenic bacteria affecting agricultural crops (flax, pumpkin, corn, beet, oranges, apricots, marrow-type pumpkin, etc.) and thus cause significant economic damage to agricultural and processing companies. Salmonella typhimurium is a salmonellosis causal agent. Staphylococcus aureus (opportunistic pathogenic bacterium) initiates skin diseases (furuncles), respiratory diseases (angina, pneumonia), nervous system and sensory organ diseases (otitis media, conjunctivitis, cerebral fever), digestive system diseases (stomatitis, acute food poisoning) and etc.

All the test samples were found to inhibit the growth of Staphylococcus aureus at low concentrations. In contrast, suppression of the reproduction of Sporosarcina ureae is an undesirable effect as they are used in agriculture.

Table 3

Evaluation of antiviral activity of the THAP hexaaza derivatives and tetrasubstituted glycolurils

\begin{tabular}{|c|c|c|c|}
\hline Sample & $\begin{array}{c}\mathrm{CD}_{50} \text { toxicity (the lowest dilu- } \\
\text { tion at which 50\% cells survive) }\end{array}$ & $\begin{array}{c}\mathrm{IC}_{50} \text { antiviral activity (the highest dilution } \\
\text { which protects 50\% cells from virus) }\end{array}$ & $\begin{array}{c}\text { Therapeutic index IS (ratio } \\
\text { of toxic dose to the efficient) }\end{array}$ \\
\hline $\mathbf{5 c}$ & $6.6 \cdot 10^{-3}$ & no & no \\
\hline $\mathbf{5 d}$ & $2.1 \cdot 10^{-3}$ & no & 1.28 \\
\hline $\mathbf{5 e}$ & $3.7 \cdot 10^{-4}$ & $2.9 \cdot 10^{-4}$ & no \\
\hline $\mathbf{6 a}$ & $5.7 \cdot 10^{-3}$ & no & no \\
\hline $\mathbf{6 b}$ & $5.0 \cdot 10^{-4}$ & no & 1.26 \\
\hline $\mathbf{6 c}$ & $5.8 \cdot 10^{-4}$ & $4.6 \cdot 10^{-4}$ & 1.57 \\
\hline $\mathbf{6 d}$ & $4.4 \cdot 10^{-3}$ & $2.8 \cdot 10^{-3}$ & 1.24 \\
\hline $\mathbf{6 e}$ & $2.1 \cdot 10^{-3}$ & $1.7 \cdot 10^{-3}$ & 1.25 \\
\hline $\mathbf{6 f}$ & $3.5 \cdot 10^{-3}$ & $2.8 \cdot 10^{-3}$ & \\
\hline
\end{tabular}


As can be seen from Table 3, only 5e propyl derivative of THAP exhibited an antiviral activity, while the methyl and ethyl derivatives did not. It was found that compound $\mathbf{5 e}$ at a concentration of $2.9 \cdot 10^{-4} \mathrm{~g} / \mathrm{ml} \mathrm{is}$ able to protect $50 \%$ of cells from influenza virus. Tetrasubstituted glycolurils 6c-e were also active at low concentrations. Further studies of the antiviral activity of these compounds were unreasonable because they had a high toxicity and a low therapeutic index. Samples $\mathbf{6 a}$ and $\mathbf{6 b}$ did not exert the antiviral activity. Note that sample 6a has found its application as a day-time sedative and is marketed as Mebicar [16]. Therefore, the biological activity of the resultant hexaalkyl derivatives of THAP should be further examined.

\section{Conclusions}

New hexaalkyl derivatives of THAP with methyl, ethyl and propyl substituents were synthesized. The conditions for the maximum product yield were selected using the example of a methyl derivative: the reaction proceeded in $\mathrm{DMSO} / \mathrm{KOH}$ at $85{ }^{\circ} \mathrm{C}$ for 13 hours with a $56 \%$ yield. The biological activity of the obtained compounds and of earlier synthesized model compounds (tetrasubstituted glycolurils) against influenza A virus was evaluated. The biological activity against the Staphylococcus aureus bacterium was exhibited by all of the test compounds, while the antiviral activity was exhibited by 2,4,6,8,9,11-hexapropyl-THAP, di-tert-butyl-dibenzyl-, di-tert-butyl-diphenyl-, di-tert-butyl-dimethyl- and di-isopropyl-dibenzylglycoluril. However, these compounds proved to be toxic to living cells.

This work was performed using instruments provided by the Biysk Regional Center for Shared Use of Scientific Equipment of the SB RAS (IPCET SB RAS, Biysk). The reported study was funded by RFBR, project number 19-33-90060.

\section{References}

1 Aizawa N. Instant low-temperature cross-linking of poly(N-vinylcarbazole) for solution-processed multilayer blue phosphorescent organic light-emitting devices / N. Aizawa, Y.-J. Pu, T. Chiba, // J. Adv. Mater. — 2014. — Vol. 26. — P. $7543-7546$.

2 Schmidt A.W. Occurrence, biogenesis, and synthesis of biologically active carbazole alkaloids / A.W. Schmidt, K.R. Reddy, H.-J. Knölker // J. Chem. Rev. — 2012. — Vol. 112. — P. 3193-3328.

3 Kotha S. Synthesis of propellanes containing a bicyclo[2.2.2]octene unit, via, the Diels-Alder reaction and ring-closing metathesis as key steps / S. Kotha, S. Pulletikurti // J. RSC Advances. - 2018. - Vol. 8, No. 27. - P. 14906-14915.

4 Huisgen R. Synthese von heterocyclenmit 1,4-dipolaren cycloadditionen // J. Zeit. Chem. — 2015. — Vol. 8, No. 8. — P. 290-298.

5 Naoki O. Synthesis and properties of tribenzocarbazoles via an acid-promoted retro $(2+2)$-cycloaddition of azapropellanes / O. Naoki, Y. Yousuke, T. Hiroshi // J. Org. Chem. - 2018. - Vol. 26, No. 8 - P. 7994-8002.

6 Torres Gómez H. Synthesis of 3-aza[4.4.3]propellanes with high $\sigma 1$ receptor affinity / H. Torres Gómez, C. Daniliuc, D. Schepmann // J. Bioorg. Med. Chem. - 2018. — Vol. 26, No. 8. - P. 1705-1712.

7 Zalkov L.H. Modhephene: a sesquiterpenoid carbocyclic [3.3.3]propellane. X-Ray crystal structure of the corresponding diol / L.H. Zalkov, R.N. Harris, D.V. Derveer // J. Chem. Soc. Chem. Commun. — 1978. — P. 420-421.

8 Beyrati M. One-pot, sequential four-component synthesis of novel heterocyclic[3.3.3]propellane derivatives at room temperature / M. Beyrati, A. Hasaninejad, // J. RSC Adv. - 2018. - Vol. 8, No. 26. - P. 14171-14176.

9 Tian X. Dichrocephones A and B, two cytotoxic sesquiterpenoids with the unique [3.3.3] propellane nucleus skeleton from Dichrocephala benthamii / X. Tian, L. Li, Y. Hu // J. RSC Advances. - 2013. - Vol. 3, No. 21. - P. 7880-7883.

10 Ashkenazi P. Propellanes: XCVIII. Treading of anti, anti[20.3.3]propellane-24,27-diol by sebacic acid / P. Ashkenazi, A.L. Gutman, D. Ginsburg // Tetrahedron. - 1988. - Vol. 44. - P. 6875-6880.

11 Shin M. Synthesis of novel 2,4,6,8,10-pentaaza[3.3.3]propellane derivatives / Shin, M., M.H. Kim, T. Ha, J. Jeon, K.-H. Chung, J.S. Kim, Y. GyuKim // Tetrahedron. — 2014. — Vol. 70, No. 8. — P. 1617-1620.

12 Lee B. Synthesis of 2,4,6,8,9,11-hexaaza[3.3.3]propellanes as a new molecular skeleton for explosives / B. Lee, M. Shin, Y. Seo, M.H. Kim, H.R. Lee, J.S. Kim, K.-H. Chung, D. Yoo, Y.G. Kim // Tetrahedron. — 2018. — Vol. 74, No. 1 - P. $130-134$.

13 Zhang J. Synthesis, structure characterizations, and theoretical studies of novel tricyclic multiple(urea) molecules / J. Zhang, Y. Liu, F. Bi, J. Zhou, B. Wang // Journal of Molecular Structure. — 2017. — Vol. 1141. - P. 268-275.

14 Sinitsyna A.A. A search for synthetic routes to tetrabenzylglycoluril / A.A. Sinitsyna, S.G. Il'yasov, M.V. Chikina, I.V. Eltsov, A.A. Nefedov // Chemical Papers. — 2020. — Vol. 74. — P. 1019-1025. https://doi.org/10.1007/s11696-019-00941-4

15 Sinitsyna A.A. N-alkylation reaction in the synthesis of tetrasubstituted glycolurils / A.A. Sinitsyna, S.G. Il'yasov // J. Sib. Fed. Univ. Chem. — 2020. — Vol. 13, No. 1. - P. 40-45. https://doi.org/10.17516/1998-2836-0164

16 Chegaev K.Yu. New functional glycoluril derivatives / K.Yu. Chegaev, A.N. Kravchenko, O.V. Lebedev, Y.A. Strelenko // J. Mendeleev Commun. — 2001. — Vol. 11. — P. 32-33. https://doi.org/10.1070/mc2001v011n01abeh001357

17 Sidwell R.W. Use of disposable micro tissue culture plates for antiviral and interferon induction studies / R.W. Sidwell, J.H. Huffman // Appl. Microbiol. — 1971. — Vol. 22. — P. 797-801.

18 Finter N.B. Dye uptake methods for assessing viral cytopathogenicity and their application to interferon assays // J. Gen. Virol. — 1969. - Vol. 5. - P. 419-427. 


\title{
А.А. Синицына, С.Г. Ильясов
}

\section{3,7,10-триоксо-2,4,6,8,9,11-гексааза[3.3.3]пропелланның алкил туындыларын синтездеу және олардың биологиялық белсенділігін зерттеу}

\begin{abstract}
Жұмыс 3,7,10-триоксо-2,4,6,8,9,11-гексааза[3.3.3]пропелланның алкил туындыларын синтездеу әдісін жасауға және алынған заттардың алкилалмасқан глколурилдермен (зерттеу объектісі) салыстырғанда биологиялық белсенділігін зерттеуге арналған. Бұл бағыт синтездің күрделілігі себебінен зерттеушілердің назарынан тыс қалған. ТНАР-ты $\mathrm{N}$-алкилдеу әдісі арқылы гексаалкилтуындыларының метилді, этилді және пропилді гексаалкил туындыларымен жаңа қосылыстары синтезделді. Метил туындысы мысалында негізгі өнімнің максималды шығымы болатындай тиімді жағдайлары жасалды. Реакция ДМСО/КОН ортасында 75-80 ${ }^{\circ} \mathrm{C}$ температурада 13 сағат бойы жүреді, реакция шығымы $56 \%$. ТНАР этилді және пропилді туындылары тура осындай жағдайда синтезделген. ТНАР-тың және гликолурилдың алынған алкилтуындыларының Sporosarcina ureae, Bacillus pumilus, Salmonella typhimurium u Staphylococcus aureus бактерияларына және А тұмауының вирусына қатысты биологиялық белсенділігі зерттелген. Барлық үлгілер Staphylococcus aureus қарсы бактериалды белсенділік көрсететіні анықталған. 2,4,6,8,9,11-гексапропил-ТНАР, ди-трет-бутилдифенил-, ди-трет-бутил-дибензил-, ди-трет-бутил-диметил-, ди-изопропил-дибензилгликолурил қосылыстарының вирусқақарсы белсенділіктен басқа тірі жасушалар үшін уытты болатыны байқалған.
\end{abstract}

Кілт сөздер: пропеллан, азапропеллан, ТНАР, гликольурил, N-алкилидеу, биологиялық белсенділік, тұмау вирусы, Sporosarcina ureae, Bacillus pumilus, Salmonella typhimurium, Staphylococcus aureus.

\section{А.А. Синицына, С.Г. Ильясов}

\section{Синтез алкилпроизводных 3,7,10-триоксо-2,4,6,8,9,11-гексааза[3.3.3]пропеллана и изучение их биологической активности}

\begin{abstract}
Работа посвящена разработке метода синтеза производных 3,7,10-триоксо-2,4,6,8,9,11-гексааза[3.3.3]пропеллана (ТНАР), который ещё не получил широкого внимания исследователей ввиду сложности синтеза, а также изучению биологической активности синтезированных соединений в сравнении с алкилзамещенными гликольурилами (объектом сравнения). Методом $N$-алкилирования ТНАР были синтезированы новые гексаалкилпроизводные ТНАР с метильными, этильными и пропильными заместителями. На примере метильного производного были оптимизированы условия получения максимального выхода целевого продукта. Реакция протекает в среде ДМСО/КОН при температуре $75-80^{\circ} \mathrm{C}$ в течение 13 ч с умеренным выходом $56 \%$. Этильные и пропильные производные ТНАР синтезированы в аналогичных условиях. Изучена биологическая активность полученных алкилпроизводных ТНАР и алкилпроизводных гликольурила в отношении бактерий Sporosarcina ureae, Bacillus pumilus, Salmonella typhimurium и Staphylococcus aureus, а также вируса гриппа А. Установлено, что все образцы проявляют антибактериальную активность против Staphylococcus aureus. Было показано, что, наряду с проявленной противовирусной активностью, у соединений 2,4,6,8,9,11гексапропил-ТНАР, ди-трет-бутил-дифенил-, ди-трет-бутил-дибензил-, ди-трет-бутил-диметил-, ди-изопропил-дибензилгликольурил также обнаружена токсичность для живых клеток.
\end{abstract}

Ключевые слова: пропеллан, азапропеллан, ТНАР, гликольурил, $\mathrm{N}$-алкилирование, биологическая активность, вирус гриппа, Sporosarcina ureae, Bacillus pumilus, Salmonella typhimurium, Staphylococcus aureus.

\section{References}

1 Aizawa, N., Pu, Y.-J., \& Chiba, T. (2014). Instant low-temperature cross-linking of poly(N-vinylcarbazole) for solutionprocessed multilayer blue phosphorescent organic light-emitting devices. J. Adv. Mater, 26, 7543-7546.

2 Schmidt, A.W., Reddy, K.R., Knölker, H.-J. (2012). Occurrence, biogenesis, and synthesis of biologically active carbazole alkaloids. J. Chem. Rev., 112, 3193-3328.

3 Kotha, S., \& Pulletikurti, S. (2015). Synthesis of propellanes containing a bicyclo[2.2.2]octene unit, via, the Diels-Alder reaction and ring-closing metathesis as key steps. J. RSC Advances, 8, 27, 14906-14915.

4 Huisgen, R. (2015). Synthese von heterocyclenmit 1,4-dipolaren cycloadditionen. J. Zeit. Chem., 83, 290-298.

5 Naoki, O., Yousuke, Y., \& Hiroshi, T. (2018). Synthesis and properties of tribenzocarbazoles via an acid-promoted retro (2+2)-cycloaddition of azapropellanes. J. Org. Chem., 26, 8, 7994-8002. 
6 Torres Gómez, H., Daniliuc, C., \& Schepmann, D. (2018). Synthesis of 3-aza[4.4.3]propellanes with high $\sigma 1$ receptor affinity. J. Bioorg. Med. Chem., 26, 8, 1705-1712.

7 Zalkov, L.H., Harris, R.N., \& Derveer, D.V. (1978). Modhephene: a sesquiterpenoid carbocyclic [3.3.3]propellane. X-Ray crystal structure of the corresponding diol. J. Chem. Soc. Chem. Commun., 420-421.

8 Beyrati, M., \& Hasaninejad, A. (2018). One-pot, sequential four-component synthesis of novel heterocyclic[3.3.3]propellane derivatives at room temperature. J. RSC Adv., 8, 26, 14171-14176.

9 Tian, X., Li, L., \& Hu, Y. (2013). Dichrocephones A and B, two cytotoxic sesquiterpenoids with the unique [3.3.3]propellane nucleus skeleton from Dichrocephala benthamii. J. RSC Advances., 3, 21, 7880-7883.

10 Ashkenazi, P., Gutman, A.L., \& Ginsburg, D. (1988). Propellanes: XCVIII. Treading of anti, anti[20.3.3]propellane-24,27diol by sebacic acid. Tetrahedron, 44, 6875-6880.

11 Shin, M., Kim, M.H., Ha, T., Jeon, J., Chung, K.-H., \& Kim, J.S. et al. (2014). Synthesis of novel 2,4,6,8,10-pentaaza[3.3.3]propellane derivatives. Tetrahedron, 70, 8, 1617-1620.

12 Lee, B., Shin, M., Seo, Y., Kim, M.H., Lee, H.R., \& Kim, J.S. et al. (2018). Synthesis of 2,4,6,8,9,11-hexaaza[3.3.3]propellanes as a new molecular skeleton for explosives. Tetrahedron, 74, 1, 130-134.

13 Zhang, J., Liu, Y., Bi, F., Zhou, J., \& Wang, B. (2017). Synthesis, structure characterizations, and theoretical studies of novel tricyclic multiple(urea) molecules. Journal of Molecular Structure, 1141, 268-275.

14 Sinitsyna, A.A., Il'yasov, S.G., Chikina, M.V., Eltsov, I.V., \& Nefedov, A.A. (2020). A search for synthetic routes to tetrabenzylglycoluril. Chemical Papers, 74, 1019-1025.

15 Sinitsyna, A.A., \& Il'yasov, S.G. (2020). N-alkylation reaction in the synthesis of tetrasubstituted glycolurils. J. Sib. Fed. Univ. Chem., 13, 1, 40-45.

16 Chegaev, K.Yu., Kravchenko, A.N., Lebedev, O.V., \& Strelenko, Y.A. (2001). New functional glycoluril derivatives. J. Mendeleev Commun., 11, 32-33.

17 Sidwell, R.W., \& Huffman, J.H. (1971.) Use of disposable micro tissue culture plates for antiviral and interferon induction studies. Appl. Microbiol., 22, 797-801.

18 Finter, N.B. (1969). Dye uptake methods for assessing viral cytopathogenicity and their application to interferon assays. J. Gen. Virol., 5, 419-427.

\section{Information about authors}

Sinitsyna, Anastasia Aleksandrovna - Junior Research Scientist at the Laboratory of High-Energy Compounds Synthesis, Institute for Problems of Chemical and Energetic Technologies, Siberian Branch of the Russian Academy of Sciences (IPCET SB RAS), Sotsialisticheskaya st., 1, 659322, Biysk, Russia; e-mail: nastya.sinitsyna.1994@mail.ru; https://orcid.org/0000-0003-3850-3132

Il'yasov, Sergey Gavrilovich - Dr. (Chem.), Deputy Director for Research, Head of Laboratory, Laboratory of High-Energy Compounds Synthesis, Institute for Problems of Chemical and Energetic Technologies, Siberian Branch of the Russian Academy of Sciences (IPCET SB RAS), Sotsialisticheskaya st., 1, 659322, Biysk, Russia; e-mail: ilysow@ipcet.ru; https://orcid.org/0000-0002-7853-6118 